\title{
The bioeconomics of homogeneous middleman groups as adaptive units: Theory and empirical evidence viewed from a group selection framework
}

\author{
Janet T. Landa
}

Published online: 22 November 2008

(C) The Author(s) 2008. This article is published with open access at Springerlink.com

\begin{abstract}
The paper presents a bioeconomics theory of homogeneous middleman groups (HMGs) as adaptive units as well as empirical evidence in the form of a number of historical case studies of HMGs functioning as adaptive units in less-developed economies lacking infrastructure. The evidence presented is not new: most of the case studies have been published [Landa (in Jenkins (Ed.) The informal sector: Including the excluded, 1988)]. What is new, however, is analyzing the phenomena of HMGs in a new way - as adaptive units viewed from a group selection perspective. In doing so, the case studies in this paper present empirical evidence of the existence and importance of group selection in human society.
\end{abstract}

Keywords Adaptation - Complex regulatory mechanisms - Major life transitions . Social norms · Institutions · Trust · Kinship · Ethnicity · Clubs · Multilevel selection · Cultural group selection · In-group cooperation · Between-group competition . Cultural bearing and transmission units $\cdot$ Dual-inheritance theory $\cdot$ Ethnocentrism

JEL Classification $\quad \mathrm{D} 23 \cdot \mathrm{D} 71 \cdot \mathrm{D} 86 \cdot \mathrm{L} 14 \cdot 017 \cdot \mathrm{Z} 12 \cdot \mathrm{Z} 13$

\section{Introduction}

In a 'Letter to the Editors' of the Journal of Bioeconomics, biologist David Sloan Wilson (2000, pp. 272-273) wrote:

Target paper.

J. T. Landa $(\bowtie)$

Department of Economics, York University, 4700 Keele Street, Toronto, ON, Canada M3J 1P3

e-mail: jlanda@Yorku.ca 
I read your paper (Landa 1999b) and enjoyed it. It fits very nicely with my new book on religion from a multilevel evolutionary perspective.... The main purpose of my book (Wilson 2002) .... is to examine the concept of religious groups as adaptive units....My empirical evidence is based mostly on detailed case studies of single religions in relation to their environments. The next step in the empirical study of religion is to become more broadly comparative. Not only should religion $\mathrm{x}$ have certain features to be adaptive in a given environment, but all religions occupying the same environment should converge on the same adaptive features. Against this background, the comparative study of middleman societies becomes especially important. If the Jews in medieval Europe, the Chinese in Southeast Asia, the East Indians in East Asia, etc. are all alike in some respects based on group-level adaptation to similar social environments, this is a very, very important example of convergent cultural evolution that needs to be showcased to demonstrate the power of the evolutionary perspective-both theory and empirical methodsfor understanding religious groups in particular and all human groups in general.

This paper is a response to Wilson's (2000) letter. I present empirical evidence in the form of a number of case studies of homogeneous middleman groups (HMGs) operating in less-developed economies in various parts of the world to showcase the empirical reality of HMGs functioning as adaptive units; hence presenting very important empirical evidence of the existence and importance of group selection in human society. But before doing so, it is necessary to revisit the evolution of my theory of the 'ethnically homogeneous middleman group' (EHMG) and link it with Wilson's discussion of human social groups as adaptive units, viewed from a group selection framework.

The paper is organized as follows. Section 2 presents the evolution of my economic theory of the EHMG: from a theory of the emergence of the EHMG as an institutional arrangement for the provision of contract enforcement, a local public good, to a signaling theory of homogeneous middleman groups (HMGs) in which symbols of individual and group identity play an important role in sorting potential trading partners into homogeneous middleman groups, to a theory of HMGs as carriers and transmitters of culture, to my current bioeconomics theory of HMGs as adaptive units viewed from the perspective of group selection theory drawn from evolutionary biology. Section 3 provides a brief discussion of the link between group selection theory and multilevel selection theory. Section 4 provides evidence of HMGs as adaptive units in the form of a number of case studies showing how various successful foreign merchant groups, originating from very different cultures, have adapted to the same underdeveloped economies of their host societies. Although the evidence comes from very different sources, it is striking how much these HMGs have in common, based on group-level adaptations to similar environmental conditions. Section 5 provides a summary and concluding comments. 


\section{A theory of homogeneous middleman groups as adaptive units: The evolution of an idea}

2.1 A theory of the emergence of an ethnically homogeneous middleman group (EHMG) as a 'club-like' institution for contract-enforcement (Landa 1981)

Based on my fieldwork on the Chinese merchants in Southeast Asia, I developed a theory of the ethnically homogeneous Chinese middleman group (EHMG) as a club-like arrangement in which Chinese traders within the group cooperated by providing themselves with club goods/local public goods such as contract enforcement, capital and information, in response to an environment lacking basic infrastructure such as legal infrastructure, banking and credit-rating institutions. By cooperating with each other, members of the EHMG were able to enforce contracts, mobilize information and capital, thereby reducing transactions costs, hence outcompeting other ethnic groups to appropriate the role of middleman-entrepreneur (Landa 1978).

Of the various club goods provided by members of the EHMG, the most important is contract enforcement. I developed a theory of the emergence of the EHMG as a club-like institutional arrangement for coping with the problem of contract uncertainty (Landa 1981, reprinted in Landa 1994, Chap. 5). I argued that under conditions of contract uncertainty, Chinese merchants will not randomly enter into transactions with anonymous traders, but will have the incentive to preferentially choose traders whom they trust, hence particularizing exchange relations on the basis of kinship, locality and ethnic ties. This is because embedded in these particularistic exchange relations are shared social norms of behavior (Confucian ethics of reciprocity) which function to constrain traders from breach of contract; any trader who violates the ethics of the group will be punished, including being ostracized from the group. The effects of many individual trader's discriminatory choice of trading partners is the emergence of an ethnically homogeneous middleman group (EHMG), a club-like arrangement alternative to contract law for economizing on contract enforcement costs in an environment characterized by contract uncertainty. Greif (1993) developed a very similar theory for the Maghribi-Jewish merchants in medieval trade. See also Tilly's (2005, pp. 8-9) discussion of Landa's and Greif's work on 'identity networks'.

The ethnic boundary of the Chinese middleman group represents the outer limits of a Chinese trader's discriminatory choice of trading partners because of the Confucian code of ethics which prescribes rules of the game-mutual aid obligations/reciprocity-for members of the same ethnic/dialect group, while not extending mutual aid to outsiders. Constraints on behavior thus exist among members of the Chinese EHMG because of shared rules of the game; members of the Chinese middleman group thus form a moral community. Confucian code of ethics serves as an informal institution, an extralegal institutional arrangement for the enforcement of contracts. 
2.2 Signaling theory of HMGs: Rituals, customs and symbols of individual and group identity (Carr and Landa 1983)

Carr and Landa (1983) extended Landa's (1981) theory of the EHMG to other homogeneous middleman groups (HMGs) including religious trading groups such as Jewish merchants in medieval Europe. Using Buchanan's (1965) theory of clubs, we depicted the optimal size of homogenous trading clubs by analyzing the economic benefits (lowered breach costs) and costs (enforcement and information costs) of belonging to a homogenous trading club, arguing that the economic benefits out-weighed the costs for a club member. We also explained many seemingly strange rituals and customs of trading groups such as Jewish dietary laws, Jews lending to fellow Jews at zero interest, Chinese keeping genealogical records, distinctive dress style, etc., as rational trading practices. First, we use signaling theory to argue that these rituals, customs and other symbols of religious or group identity — such as names, clan names, dietary rules, language, dress, and religion-play an important signaling function in transmitting non-price information of the identity of potential trading partners, and hence serve to economize on information costs of identifying each other. Secondly, we argue that these symbols and rituals of group identity screen out outsiders by erecting barriers to entry for those outsiders who may wish to free-ride on the benefits of club membership. We analyze these two functions of group rituals, and other symbols of group identity by analyzing, for example, Jewish dietary laws:

....Jews have a stringent set of dietary laws known as the kashruth. Why do members of these religious organizations restrict their eating behavior when there seem to be no apparent benefits from doing so? We argue that there are benefits. Dietary laws give religious members a feeling of shared values. These shared values give members of the religious organizations a sense of a common identity and distinguish them from non-members. It is exactly this difference between members and nonmembers that is needed to facilitate economic exchange under conditions of contract uncertainty.... Dietary laws also help identity club members, an especially important function if club members are geographically dispersed. Dietary laws discourage conversion by increasing the costs of joining the organization and thus serve as a barrier against those seeking to become members in order to receive the economic benefits (Carr and Landa, 1983, p. 153-154). See also Iannaccone (1992) who developed a very similar theory of the function of religious rituals.

In addition, Carr and Landa analyzed the optimal size of the ethnic trading club/ network as the club expands to include increasing number of insiders while excluding outsiders from the ethnic trade network.

Cooter and Landa (1984) extended Carr and Landa's (1983) formal club-theoretic model of the HMG one step further by analyzing the relationship between the size of trading groups and the development of the law of contracts. We think of a trading group as an informal club-like arrangement for reducing breach of contract between members. If the group expands, then members gain the advantage of a more extensive internal market. On the other hand, as the group expands, personal relations become 
attenuated. For a given level of expenditure by the group on enforcement, the probability of breach will increase as the group becomes larger. We prove that membership in clubs will decline if contracts with outsiders become more secure i.e. when contract law becomes better developed.

Recently, Bowles and Gintis (2004) developed a theory of trust embedded in "parochial' ethnic networks very similar to that developed by Landa (1981), Carr and Landa (1983), and Cooter and Landa (1984).

\subsection{A theory of HMGs as 'cultural bearing' and 'cultural transmission' units (Landa 1991)}

Once HMGs emerges, what factors account for the persistence of ethnic trading boundaries? The answer lies in viewing a HMG explicitly as a 'cultural-bearing unit', anthropologist Barth's (1969) concept of an ethnic group - instead of implicitly as in the Carr and Landa (1983) paper - and as a 'cultural transmission unit' (Landa 1991), following Boyd and Richerson's (1985) theory of co-evolution of genes and culture or 'dual inheritance theory', which focuses on the importance of cultural group selection.

In Landa's (1991) paper, a HMG is viewed explicitly as a 'cultural bearing' unit because members use symbols of individual and group identity, including physiognomic indicators, to convey low cost non-price information of a trader's reputation for trustworthiness to potential trading partners who are members of their own ethnic group. At the same time, these symbols of group identity erect barriers to entry for outsiders who may wish to 'pass' as insiders in order to improve their status by freeriding on the benefits of group membership. Such passing include changing names and religious conversion. But an outsider from a very different ethnic/racial group cannot change his ethnicity because ethnicity involves immutable physical characteristics. It is very costly for a person from a different ethnic group to switch ethnic identities. Switching an identity via assimilation is a long-term process, the "costs of ethnic identity switching are so prohibitive, both in the short and long run, ethnicity imposes an effective barrier for those attempting to pass as insiders' (Landa 1991, p. 66). I compared ethnicity as a hard-to-fake ethnic marker which is analogous to the peacock's elaborate tail discussed by biologists (e.g., Hamilton and Zuk 1989) as performing two important functions: 'as identification of conspecifics, and as a screening device to screen out the weak, or cheaters/fakers' (Landa 1999a, p. 105).

Once the HMG emerges, the HMG functions as a 'cultural transmission unit' which operates to maintain the HMG over time. I developed a theory of the HMG as a cultural transmission unit, using Boyd and Richerson's $(1980,1985)$ 'dual inheritance theory' of genes and culture:

Since many of the family firms of the deceased middlemen will be passed on to sons, social learning of the culture of the middleman group takes place through docility and 'frequency-dependent bias'-sons copying the behavior of their fathers-without the need for costly trial-and-error learning. The next generation can also copy those middlemen-entrepreneurs who are especially successful and have emerged to assume roles as leaders and philanthropists in their own 
community. Since the enculturation process of social learning also goes on in the wider ethnic community of which the EHMG is a subgroup, new members of the ethnic group will also inherit the cultural values of the group. The rules of the game and other cultural values governing members of the present generation of middlemen, then, will be transmitted via social learning from one generation to the next....Ethnocentrism of members of the EHMG is reinforced; those who are already in the middleman group will continue to prefer to choose new trading partners from the younger generation of the same ethnic group (Landa 1991, p. 69-70).

HMGs function as 'cultural transmission units' because wealthy members of the HMG play an important role in providing certain local public goods, including education to fellow members, and because group cultural values are transmitted to future generations of the ethnic group via teaching (in schools and in the family) and learning from peers. The ethnic boundaries of trading networks thus persist over time because of: (1) the 'conformist transmission' bias, i.e. copying from peers, etc. (Boyd and Richerson 1985); and (2) the 'efficiency' of the HMGs as a cultural bearing unit, and as a cultural transmission unit, using the concept of efficiency as defined by bioeconomist Jack Hirshleifer (1982, p. 50):

On all levels of life organisms have found it profitable to come together in patterns of cooperative association. But such cooperation is always secondary and contingent, in at least two respects: (1) in-group cooperation is only a means for more effectively and ruthlessly competing against outsiders, and (2) even within the group there will not be perfect parallelism of interests, hence cooperation must generally be supported by sanctions....Efficiency, in this interpretation, is meaningful only as a measure of group strength or advantage relative to competing groups in the struggle for life and resources.....A totally universalistic measure of efficiency is pointless; we must draw the line somewhere, at the boundary of 'us' and 'them.'

Hirshleifer's concept of 'group competition', ignored in conventional economics, is crucial to my explanation of the emergence and persistence of EHMGs: 'In the ruthless competitive inter-ethnic struggle for profit opportunities, in-group members with efficient social structures for the enforcement of cultural norms of behavior have a comparative advantage over other ethnic groups in appropriating and maintaining middleman-entrepreneurial roles for themselves (Landa 1991, p. 71). By 1991, using Hirshleifer's concept of efficiency and group competition, I came very close to developing a bioeconomics theory of the HMG as an adaptive unit. But that theory still took some years to materialize. In the interim, I came across biologist Alexander's (1987) theory of the origins of moral systems:

Moral systems are societies with rules. Rules are agreements or understanding about what is permitted and what is not, about what rewards and punishments are likely for specific acts, about what is right and wrong. I will argue that the concepts of moral systems have been designed to assist group members and explicitly not to assist the members of other competing groups. [Emphasis added] 
Alexander (p. 79) argued that inter-group competition promotes in-group cooperation via the role of moral systems: '[H]umans alone play competitive group against group on a large and complex scale.' Moral systems, rules or institutions thus divide human society into groups: 'us' vs. 'them', 'insiders' vs. 'outsiders'. This ethnocentric propensity of humans to cognitively classify people into 'us' and 'them' led me to develop a classificatory theory of HMGs, and to coin the term 'Homo classificus' for humans (Landa 2002).

It was not until I read Sober and Wilson's (1998) book that I developed a bioeconomics theory of Chinese middleman success and placed it explicitly on group selection-bioeconomics foundations (Landa 1999b). And not until I read Wilson's (2000) commentary on my paper, that I realized that I have sufficient number of case studies of various middlemen group-level adaptations to similar underdeveloped environment in various parts of the world (Landa 1988). So even though the empirical evidence of HMGs functioning as adaptive units was in front of my face for over a decade, I could not see it until many years later. ${ }^{1}$ And I am sure that I would never have seen it, if it were not for the fact that I had crossed over from the social sciences to evolutionary biology, that I was able to interpret HMGs in a new way, as adaptive units.

\subsection{A bioeconomics theory of homogeneous middleman groups (HMGs) as adaptive units viewed from a group selection perspective}

In order to develop a bioeconomics theory of HMGs as adaptive units, it is necessary to understand the meaning of 'adaptation' and also the meaning of a 'group' as an adaptive unit from the perspective of multilevel selection theory. (For a brief discussion of the distinction between the concepts of group selection and multilevel selection, see Sect. 3) In evolutionary biology, 'adaptation' is defined as 'the process populations of organisms acquire properties that allow them to survive and reproduce more effectively, by being able to cope with their environment' (Ghiselin, e-mail communication, April 1, 2008). Stated more generally, '....adaptation designates any process whereby a structure is progressively modified to give better performance in its environment. The structures may range from a protein molecule to a horse's foot or a human brain or, even, to an interacting group of organisms such as the wildlife of the African veldt' (Holland 1975, Preface, p. v).

A group is defined as 'a set of individuals that influence each other's fitness with respect to a certain trait but not the fitness of those outside the group' (Sober and Wilson 1998, p. 92). When the trait is a social behavior, Wilson (2002, p. 15) says that 'the fitness of an individual is determined by its own trait and the traits of the individuals with whom it interacts, coining the term 'trait group' (Wilson 1975) to emphasize the close relationship between traits and groups in multilevel selection theory. More generally, a trait group is defined 'in terms of the individuals who interact with respect

\footnotetext{
${ }^{1}$ As (Wilson 2002, p. 133) so aptly puts it: 'There are certain things in front of our faces, and our challenge is to discover the theoretical framework.' The real life phenomena of HMGs in various parts of the world sharing the same traits in response to the same environment can be viewed afresh from the theoretical perspective of multilevel selection theory.
} 
to a given activity' (Wilson 2002, p. 15). ${ }^{2}$ Thus 'my bowling group is the people with whom I bowl, my study group is the people with whom I study...(Wilson 2002, p. 15).

In the case of the homogeneous middleman group, it is a network of interdependent middlemen linked to each other directly and indirectly by particularistic ties of kinship, locality, and ethnicity.

In order to understand a human group as an adaptive unit, Wilson (2002, p. 25) says that it is necessary to 'go beyond kin selection and reciprocity to model a complex regulatory system that binds members of a group into a functional unit." ${ }^{3}$ Wilson's emphasis on the importance of 'complex regulatory systems' such as social norms (see Sober and Wilson 1998, Chaps. 4 and 5) reflects an emerging biology paradigm of major-life-transitions in which members of groups, through regulatory mechanisms, suppress conflict/free-riding within the group, thus allowing group members to cooperate for their collective benefit — without undue self-sacrifice ('altruism') of it members-hence the group's success in out-competing other groups. ${ }^{4}$ Wilson's emphasis on 'complex regulatory systems' is to be understood in the context of his discussion of multilevel selection theory which focuses not only on within-group cooperation, but also importantly on between-group competition. Wilson's multilevel selection perspective revives group selection theory, albeit in its rehabilitated form.

The 'complex regulatory system' that Wilson refers to is equivalent to the concept of 'institutions' - formal and informal 'rules of the game' - central to New Institutional Economics (see Landa 1994, Chap. 1). An example of a formal institution is contract law. Examples of informal institutions are social norms, ethical codes of conduct, religion, etc.

By 1999, I was able to develop what essentially is a bioeconomics theory of the HMGs as adaptive units incorporating the following essential elements (Landa 1999b):

(a) An immigrant group responds to the existence of an economic opportunity or an economic niche-for example, opportunities for middleman-entrepreneurshipin the host country;

(b) The immigrant group is a minority ethnic group co-existing side by side with other ethnic groups - including the indigenous population-who are potential competitors for occupying the middleman niche;

(c) The infrastructure necessary for entrepreneurship — contract law, banking, creditrating institutions - is poorly developed or non-existent;

\footnotetext{
${ }^{2}$ I thank David Sloan Wilson for sending me a galley proof copy of his book (Wilson 2002) prior to the book's publication.

${ }^{3}$ Wilson identifies three mechanisms for achieving in-group cooperation: kinship, reciprocity, and social norms. For additional pathways to cooperation, see Hirshleifer (1999).

${ }^{4}$ For an example of major transitions paradigm in evolutionary biology, see Michod (1997). Michod studies the transition in evolution 'from cells to multicellular organisms, saying that 'the two issues considered are applicable to all major transitions in the units of evolution that share two themes: the emergence of cooperation and the regulation of conflict among the lower-level units, in this case cells' (p. 607). Michod says that 'the major transitions in evolution are from individual genes to networks of genes, from gene networks to bacteria-like cells, from bacteria-like cells to eukaryotic cells with organelles, from cells to multicellular organisms, and from solitary organisms to societies' (p. 607).
} 
(d) To be successful in middleman-entrepreneurial role, middlemen must be able to provide themselves with infrastructure by providing themselves with club goods;

(e) Several club goods such as contract enforcement, provision of capital and information can be obtained by middlemen only if there is cooperation and coordination among middlemen functioning as an adaptive unit, in response to the poorly developed infrastructure;

(f) By forming a HMG, with members connected by kinship, ethnic, religious and other personalistic ties, social norms exist among members of the HMG to facilitate cooperation and collective action for the provision of club goods;

(g) Members of HMGs, by cooperating and coordinating their activities, by providing themselves with club goods, can out-compete other ethnic groups to appropriate middleman roles;

(h) By transmitting cultural values of trustworthiness and cooperation to the next generation of middleman, HMGs can persist over time.

(i) The persistence of HMGs — with ethnic boundaries separating 'us/insiders' from 'them/outsiders' is a source of inter-ethnic conflict and violence in multi-racial societies. See also Corning's (2007) bioeconomics theory of collective violence in non-human and human societies.

\section{Current status of group selection theory and multilevel selection theory}

Group selection (GS) and multilevel selection (MLS) are closely related but not identical concepts. In two important recent articles aimed at rethinking the old controversies surrounding GS theory since the 1960s, Wilson and Wilson (2007, p. 345; 2008), concluded with a summary of sociobiology's new theoretical foundation: 'Selfishness beats altruism [read: cooperation (my emphasis)] within groups. Altruistic groups beat selfish groups.'

It is clear that MLS theory focuses on at least two biological levels of selection and multiple groups in a population structure:

(a) a lower level 'individual selection' or 'within-group selection' where unrestrained free-riders/cheaters/selfish genes by maximizing their relative fitness within the group outcompete cooperative members; and

(b) a higher level selection, 'between-group selection', where cooperative groups (using social controls to restrain free-riders), favors behaviors that increase the relative fitness of the whole group, hence outcompete selfish groups. MLS theory allows for the possibility that adaptations can evolve above the level of individual organisms, i.e. at the level of social groups and other higher level units, and hence according to Wilson and Wilson (2007, p. 336), Dawkins' (1976) 'selfish gene' paradigm that the individual gene is the fundamental and the sole unit of selection is wrong.

On the other hand, GS theory focuses on the 'between-group selection' levelthe evolution of cooperative traits-in which cooperative groups outcompete selfish groups. The logic of GS theory is thus embedded in a larger and more comprehensive MLS theoretical framework, a framework which is likened to a series of nested Russian dolls (Wilson and Wilson 2008, p. 380). 
Wilson and Wilson (2007, p. 339) says that despite the controversial history of MLS theory, that the theory is an accepted theoretical framework for the study of 'major transitions'-e.g. single cells evolving into multi-celled organisms, honeybees evolving into the eusociality (i.e. extra high sociality) of honeybee colonies ${ }^{5}$ — where selection within groups is suppressed, thus allowing selection among groups to emerge.

It is important to emphasize for bioeconomists, that GS and MLS theories are sociobiological theories of biological evolution that emphasize natural selection which is based on survival and reproduction expressed in biological terms of relative fitness comparisons. Such relative fitness comparisons have no conceptual counterparts in economics when discussing the evolution of the firm, industry, markets, etc. As Metcalfe (2008, p. 25) states: 'economic evolution is not biological evolution for [there is] nothing in the economic world to correspond to the exact processes of biological inheritance, sexual reproduction and gene transmission over time.' However the basic GS theoretical framework can still provide a powerful bioeconomics framework for understanding how one trading group comes to dominate middleman-entrepreneurial roles: If traders can form a homogeneous middleman group and can cooperate and coordinate their collective efforts in the provision of local public goods, and are able, via social controls and social norms, to punish selfish individuals (free-riders in the group who wish to benefit from public goods without contributing), then the trading group can outcompete other less cooperative groups, in functioning as a group-related adaptive unit in providing public goods for group members, hence able to appropriate and maintain the role of middleman-entrepreneur. As Wilson and Wilson (2007, p. 343) noted: 'The psychological traits associated with human moral systems are comparable to the mechanisms that suppress selection within groups for other major transitions, such as chromosomes and the rules of meiosis within multicellular organisms and policing mechanisms with eusocial insect colonies.' This is exactly the group selection framework that is used in Sect. 2.4 of my bioeconomics theory of HMGs as adaptive units. $^{6}$

Once the HMG emerges, cultural group selection plays an important role in helping the HMG to persist over time via its role in transmission of social norms to future generations of middleman. Here, the theory of gene-culture co-evolution associated with the work of Lumsden and Wilson (1981, revised and expanded 2005 edition) and Boyd and Richerson's (1985, Richerson and Boyd 2005) 'dual inheritance theory' are relevant, although in Sect. 2.3 of this paper, my focus is exclusively on Boyd-Richerson's dual inheritance theory emphasizing cultural group selection. ${ }^{7}$

Wilson and Wilson's (2007, especially 2008) articles also provided empirical evidence for group selection mostly drawn from non-human societies. The next section of the paper will provide empirical evidence for the existence of group selection in human societies in the form of a number of case studies of HMGs.

\footnotetext{
${ }^{5}$ For the bioeconomics of honeybee scouts using the unanimity voting rule for collective choice of a new nest, see Landa (1986).

${ }^{6}$ For the bioeconomics literature on group selection, see Buchanan (2000), Rubin (2000), and Gifford Jr. (2000).

7 My paper does not address biological group selection which, according to Field (2001, 2008), needs to be included in a comprehensive theory of human behavior.
} 


\section{Homogeneous middleman groups (HMGs) as adaptive units: Some case studies}

This section provides empirical evidence-in the form of several case studies - that successful trading groups are adaptive units with shared traits in common. The following are brief summaries of mostly prior work on case studies of merchants in various parts of the world, either based on my own fieldwork (Landa 1978, 1983) or drawn from the studies by other scholars (Landa 1988). ${ }^{8}$

\subsection{Chinese middlemen in Southeast Asia (Landa 1978, 1981, 1983, 1988)}

The marketing of smallholders' rubber in West Malaysia is dominated by a particular Chinese ethnic/dialect group_-Hokkien-Chinese traders-who function as middlemen between smallholders (largely indigenous Malay population ) and overseas buyers. In 1967 there were 2,240 licensed rubber dealers in West Malaysia. Members of the middleman group were arranged in a pyramidal marketing structure with specialization and division of labor among the different levels of middlemen: village dealers, town dealers, and packers/exporters.

A closer scrutiny of the Chinese middleman group in Singapore and West Malaysia revealed the existence of a tightly knit ethnically homogeneous Hokkien-Chinese group. Within the Hokkien-Chinese group, five clans from Chuan-chow and Yungchung counties in Fukien province in China-Tan, Lee, Ng, Lim, and Gan-dominated the marketing network. The Hokkien ethnic community is the most wealthy and powerful of the five major Chinese ethnic/dialect groups (Hokkien, Teochew, Cantonese, Hakka, and Hainanese) by virtue of their dominance of the smallholders' rubber trade (see Landa 1978, Chap. 3; 1988). Of the Tan clan in Southeast Asia, Tan Kah Kee emerged to become the 'Rubber King' by 1925. Using part of his profits from his business enterprises, Tan Kah Kee, as 'Rubber King' and as leader of the Hokkien Huay Kuan (the Hokkien dialect association), engaged in philanthropy by financing the provision of much needed local public goods such as elementary and middle schools and the Amoy University for fellow villagers and fellow Hokkiens in his native province of Fukian as well as schools for fellow Hokkiens in Singapore. See Landa and Salaff (1980, 1986 revised).

Interviews that I conducted with a number of Hokkien rubber dealers in Singapore and West Malaysia revealed the importance of the role of kinship and ethnic ties as a basis for establishing mutual trust and the informal sanctions that operated to enforce contracts. One rubber dealer said:

Because of the risks involved in advancing money without security, based purely on trust, we tend to trade with those whom we trust; they are often kinsmen, friends, people from the same place in China and those who speak the same dialect. Because of the longer association of Hokkiens with each other in the rubber

8 The case studies not included in Landa (1988) are: Chinese merchants in People's Republic of China (Sect. 4.2); Indian merchants in India: the Jains-Marawari traders (Sect. 4.3), and Indian traders in South Africa (Sect. 4.5). 
industry, we find it easier to give credit to a fellow-Hokkien because there are ways of finding out the creditworthiness of that person-about his background, his associates, his ethical code and so on (Landa 1983, p. 90-91).

The 'ethical code' refers to the traditional Confucian code of ethics which overseas Chinese in Singapore and Malaysia have adapted to their new homeland where the Chinese community as a whole constitute an ethnic minority amongst the Malay majority. Beyond the role of ethics embedded in particularistic exchange relations, social sanctions existed for punishing those who deliberately breach the trust of their trading partners: shaming a person, withdrawal of credit, and ostracism from the trading network (Landa 1981, 1988, pp. 83-84).

The following case which I obtained from an interview with a rubber dealer dramatically reveals a Chinese rubber dealer's attitude towards those who do not abide by the rules of the game of the group:

Mr. X was sued by his creditors. He was unable to pay his debts. To make matters worse, he showed contempt and spite towards his creditors. Mr. Y, a creditor, was very angry with his debtor. He was on a business trip to Hong Kong but flew back to Singapore to attend the court case. The case was initiated by the whole group of creditors. Mr. Y said that the case involve only a few thousand dollars. But he was willing to pay for the trip back to Singapore and then return to Hong Kong to finish his business deal. The airfare plus lawyers' fees all added up to a significant amount. In fact he lost more money by prosecuting the debtor. But he did it simply because the debtor did not show respect for the principles of Chinese methods of conducting business. When he could not pay his debt, instead of attempting to remedy the situation, he worsened it by showing contempt for his creditors. Mr. Y said, 'this man is not suitable to remain in the business community; he does not deserve cooperation or help from his colleagues' (Landa 1988, p. 94)

This case study provides an excellent example of prosocial behavior in the form of 'altruistic punishment' (Fehr and Gächter 2002) in which an individual in an ethnic trading network is willing to punish another individual in the same network, at a cost to himself by ostracizing the offending party from the Chinese business network.

\subsection{Chinese merchants in People's Republic of China (Watson 1988)}

Since embarking on an ambitious program of economic reforms in 1978, the People's Republic of China (PRC) has enjoyed a degree of success in making the transition from a centrally-planned economy to a market-oriented economy. The major economic reform took place in rural China with the introduction of the Household Responsibility System (HRS). The HRS de-collectivized people's communes by reintroducing the family farm. Farmers, after fulfilling their government quota, have the right to sell their surplus in private markets where prices are higher. As a result of the HRS the number of rural and urban markets increased, and with it the emergence of a network of middlemen connecting rural with urban markets. Watson noted the existence of social and cultural ties between the newly emergent network of middlemen. I interpreted the 
existence of homogeneous particularistic network of middlemen as a response to the environment of contract uncertainty in PRC's transition to a market-oriented economy (Landa 1998).

\subsection{Indian merchants in India: the Jains-Marwari traders (Iyer 1999; Laidlaw 1995)}

Iyer's (1999) paper outlines some fundamental features of dominant Indian merchant groups, focusing especially on the Jains-Marwari traders. The Indian merchant community as a whole belongs to the Vaishyas caste, one of the four hierarchically ranked Hindu castes in descending order of status: the Brahmins (priests), the Kshtrigas (warriors), the Vaishyas (traders), and the Sundras (peasants and laborers). Besides caste homogeneity, the Hindu merchant communities are subdivided into merchant groups according to their place of origin.

The dominant merchant communities are the Marwaris, traders who originated from Marwar in Northwest India, and the Gujaratis originating from Western India, including Bombay. Marwari merchant communities are further sub-divided into various smaller more tightly-knit homogeneous 'jatis' (family descent) 'the endogamous hereditary and named social groups...' (p. 104) 'It is the jati...that clearly identifies the social group to which a particular merchant belongs...(p. 104). And it is the organization of the merchants into jatis, that led to the establishment of codes of conduct for each jati, which 'translates into strong sources of credit' (p. 107).

Furthermore, Marwari traders are united by a common religion, Jainism, a religion which 'not unlike Buddhism, prescribes definite codes of conduct for monks and laities alike and the laity is expected to follow 'lesser vows' comparable to the 'great vows of the ascetic' (Iyer p. 106). An ascetic lifestyle, however, is not inconsistent with the accumulation of wealth, as Iyer (p. 106) explains: 'The frugal Jain lifestyle and inner-worldly asceticism finds parallels with Weber's "Protestant Ethic".' See also Wilsons's (2004) discussion of the relationship between Jainism and Jain merchants. And indeed, I might add: it is this 'Protestant ethic' with its emphasis on asceticism together with the concept of 'calling', that Weber used to develop this theory to explain why Protestants, and not Catholics, dominated entrepreneurial roles in Europe.

In India, wealthy merchants are also very religious: they contribute generously to donations to temples, social and other educational institutions (p. 106), This in turn increase their reputation in the merchant community. A merchant who has a good reputation is able to access informal financial credit and market information (p. 109). Wealthy Jains merchants dominate the emerald gem export market. They extend credit to each other, and use the hundi, a kind of promissory note whose use requires a great deal of trust. Loss of credit and reputation results if a dealer did not pay the debt in full and upon demand (Laidlaw 1995, p. 354; see also Wilson 2004).

A merchant family's good credit and reputation is also facilitated by good arranged marriage alliances (Laidlaw 1995, p. 335). The result of personalized exchanges, based on ties of jati, caste, locality and religion, among Jains-Marwari merchants is that, 'Jain businessmen throughout India and beyond have consistently fit into particular commercial niches and making use of ready-made networks of credit and social relationships...' [(Iyer, p. 108 citing Dundas (1992, p. 169)]. 


\subsection{Indian merchants in Central Africa (Dotson and Dotson 1968)}

The largest single foreign ethnic group involved in the African trade as middlemen in the 1960s was the Indians. The Indians came from India to Africa through their early connections with Arabs and Portuguese, and especially with the British. Because of their historical ties with Britain, they are mostly found in British East and Central Africa (Rhodesia, Zambia and Malawi) than elsewhere in Africa.

The middleman role in Rhodesia, Zambia and Malawi is dominated by Hindu Indians coming from peasant families in the Gujarat region in India. The group is tightly knit, consisting of kinsmen bearing the surname of Patel associated with the Patidar caste. There is a high degree of internal solidarity among the Patidar merchants not only because of the existence of kinship ties but also of caste ties. In India, members of Hindu society are born into a particular caste for which they have life-long membership and from which they cannot escape from their caste status. Each caste has its own values and norms. With no option to cross caste boundaries, this means that the Hindu caste code prescribes a high degree of mutual cooperation among caste members. Dotson and Dotson (p. 66) explain why Indians in Central Africa were successful in their middlemen roles: 'The same culture provide them with normative basis for effective social cooperation in small tightly knit kinship, caste and locality groups.'

The Gujarati Indians are especially prominent in the more profitable wholesale African trade where almost all sales are made on credit. How do they minimize credit default? Unlike the Europeans in Africa who resort to formal contracts in their business dealings, the Indians use the status of kinship, caste and religion in their dealings with each other to protect against credit risks. With increasing competition from African traders at the retail level, Indian wholesalers are prepared to do business with African retailers, but they fear the risks of credit default.

\subsection{Indian traders in South Africa (Godsell 1991)}

Godsell (1991) described the homogeneous network of Indian traders in South Africa where Indian entrepreneurs were mainly Muslims. Family, religious and friendship networks play an important role in Indian business success: Indian entrepreneurs obtained import/export contacts as well as start up capital from family, friends and coreligionists. The Indian businessman prefers to extend help, 'first to a family member, second to a coreligionist, third to another Indian' (p. 87). Their success was due to the fact that 'they were able to draw on their religious, family, and ethnic resources to overcome the obstacles placed in their way by legislative and social discrimination' (p. 89).

\subsection{The Lebanese traders in West Africa (Dotson and Dotson 1975)}

The Lebanese traders came to West Africa around 1900. Dotson and Dotson (1975, p. 589) comparing the Lebanese with the Indians, offer the following explanation of Lebanese merchant success: 
Although quite different in major ethnological characteristics, these two Oriental peoples were remarkably similar in those aspects of traditional culture and social structure that predisposed them to success in business. Both, for example, possessed a family system extended beyond the immediate 'nuclear' unit of parents and dependent offspring. The extended family is conducive to successful business entrepreneurship in two ways. At the value level, the strong sense of obligation and family continuity inculcated by it helps to create and constantly reinforce the future orientation that we have described as a shopkeeping prerequisite. Organizationally, on the other hand, the small, tightly knit unit so created provides the foundation for co-operative action, capable of transcending the limitations of either the capital resources or the functional capabilities of single individuals. Particularly when initial resources are small, this capacity gives such a group tremendous competitive advantages over isolated individuals....Indians and Lebanese came from peasant villages, it is true; but as Orientals they also came from societies in which commerce and trade were anciently established and well-understood in principle, even by their peasant populations.

\subsection{Jewish merchants in medieval Europe and elsewhere}

\subsubsection{Jewish merchants in medieval Europe (Zenner 1983)}

Jews played a prominent role as merchants in long-distance Mediterranean trade in the Commercial Revolution of the Middle Ages, 950-1350. In the long-distance trading networks, Jews played an indispensable role in the medieval city-state of Venice, linking the Italian merchants with other foreign merchants who came to Venice to trade during the heyday of the Venetian empire. According to Zenner (pp. 151-152) the medieval development of the Jews as a trading diaspora-a network of dispersed trading settlements - was made possible by the organization of trust over long distances:

... long-distance trade centered around family firms and often ethnically and culturally homogeneous groups. Common ancestry, languages, and religion provided the basis for a moral community which could enforce ostracism (for example, boycott, ex-communication) when no common territory existed....The fact that such a moral community over long distances supports trade also reinforces the diaspora as a whole, since the survival of the group depends on having communications, distinctiveness, and a way of enforcing its norms over great distances. Being involved in an occupation with other members of one's group means that your livelihood depends on your fellow kinsmen and co-ethnics (co-religionists) and makes leaving the group more difficult.

\subsubsection{Jews in Jerba, Tunisia (Udovitch and Valensi 1984)}

By the first half of the eleventh century, Jews in Jerba emerged as a well-established community. They participated in the Commercial Revolution of the Mediterranean 
world: they were engaged in trade that extended from Spain through Tunisia and Sicily to Egypt and beyond to South Arabia and India. As part of the international network, they traded not only with co-religionists from Tunisia and Egypt but also with Italians from Amalfi, Genoa, and Venice who came to North Africa to trade.

Within Jerba, the Jews dominated two occupations, textiles and the jewelry trade. It is precisely in the jewelry trade, where mutual trust is crucial between exchange partners, that:

the clientalization of exchange does not cross ethnic boundaries but takes place between the Jewish producers in the Jara and their co-religionists merchantdistributors in the suq (p. 117).

Within the close-knit social and economic network, the mutual trust between the jewelers are based on Jewish cultural and legal traditions. The Jews, according to Udovitch and Valensi, are 'people of the law' and adhere strictly to the law. The same values of trust and integrity in business dealings among the jewelers, are also extended to economic transactions across religious boundaries in economic transactions with Muslims in the suq/market (Udovitch and Valensi p. 29).

Furthermore, Udovitch and Valensi (p. 111) pointed out the multiple roles the Jerban Jewish jeweler played in the Jewish community:

....individual jeweler fulfill several functions in different spheres simultaneously. A Jewish jeweler is not simply a jeweler; he may also be the head of a synagogue, a part-time scribe, the community circumciser, or a member of the burial society. In Jerba, possessing the skills to produce or sell jewelry is not enough to make one a jeweler. One has, first and foremost, to find a place within a closely knit social -even more than economic-network. Since similar rules govern other occupations, it is once again, according to ethnic, religious and communal affiliations that the division of labor operates and perpetuates.

\subsubsection{Jews in present-day Antwerp, Amsterdam and New York (Gutwirth 1968)}

The number of Jews living in Antwerp, Belgium in 1966 was estimated to be 10,500 out of a total population of 550,000. Antwerp, a major center of commerce and industry, is one of the largest ports in the world. About $80 \%$ of the Jewish population dominated the diamond industry, import-export trade and in the occupation of cleaving (transforming rough diamond into brilliant ones). Diamond transactions require a great deal of trust on the part of dealers because of the need to constantly bargain and negotiate about the quality of diamonds transacted between buyers and sellers, and because of the opportunities for theft and fraud. This explains why the diamond trade:

takes place within a comparatively close and limited group: the participants (often linked by friendship) are formed into a loose type of association with its own codes and sets of rules to which they adhere...Yiddish, a true lingua franca of the diamond community emphasizes the confidential nature of the economic arrangements (Gutwirth p. 133). 
The group involved in the diamond trade and industry is a highly homogeneous religious group whose members speak the same language, Yiddish (Gutwirth p. 124). Within the group, there is a further specialization and division of labor along religious lines: the export trade is dominated by the less orthodox Jews, while the ultra-orthodox Hassidic Jews-identified by their long beards, sidelocks, gaberdines and fur hatsdominate the import/local diamond markets.

Hassidic Jewish merchants in Antwerp, like the Jews in Jerba, played multiple roles in their community: They played an important role in maintaining Jewish cultural identity via dietary laws (kashrut) and other religious and ritual practices. Prominent members of the diamond trade and industry were often also the leaders of the various associations and cultural clubs whose functions include assisting immigrants from Central Europe into Antwerp, promoting tsedake (charity and solidarity as it was practiced in Central and Eastern Europe), as well as various cultural functions.

The same attributes of honesty and reliability in transactions explains why the diamond trade in Amsterdam and in New York is dominated by a close-knit group of Jews who conduct transactions among themselves without relying on the state for the enforcement of contracts. For more recent empirical studies of diamond merchants in New York, see Bernstein (1992), Richman (2006). ${ }^{9}$

\section{Summary and conclusions}

From the case studies of various successful merchant groups operating in underdeveloped countries and elsewhere in present-day Antwerp, Amsterdam and New York, we observe that these successful middleman groups share the following adaptive characteristics:

1. Middlemen belong to tightly-knit groups so that middleman exchange-with specialization and division of labor among middlemen - is characterized by personalistic exchange based on kinship, ethnic or religious ties. The greater the degree of trust involved in transactions, the more homogeneous and tightly knit the HMG becomes, e.g. the Yiddish-speaking Hassidic Jews dominate the diamond trade in Antwerp and in New York, while the very religious Jains-Marawari traders dominate the emerald gem trade. ${ }^{10}$

2. Kinship and ethnic ties, as well as shared social norms embedded in these HMGs serve as constraints on the behavior of group members, and hence functioned to provide members with club goods.

3. Wealthy members of the HMGs who are also leaders of their own ethnic communities, especially Chinese and Jewish merchants, played key roles in transmitting cultural values to future generations of merchants via their roles in promoting education, etc.

\footnotetext{
${ }_{9}$ Even present day Jewish merchants engaged in diamond trade in Antwerp, Amsterdam, and New York are HMGs. It is not that the legal framework is not well-developed, but because Jews long had a monopoly of the diamond trade, a monopoly due to their ability to enforce contracts among themselves in the days when contract law was not well-developed.

${ }^{10}$ For many other HMGs in cross-cultural trade, see Curtin (1984).
} 
My empirical evidence on various HMGs_-based on my own field work, and drawn from other scholars' historical and ethnographic studies, shows that not only the Chinese merchants in Southeast Asia have adapted themselves to the environment of underdevelopment by forming an ethnically homogeneous middleman group, with shared Confucian social norms, so as to provide group members with club goods, but other trading groups occupying similar environment of underdevelopment in other parts of the world also converged on the same adaptive features. The formation of HMGs, with social/religious norms embedded in these kinship and particularistic trading networks, provide an important example of convergent cultural evolution, and hence demonstrating the power of multilevel evolutionary perspective for understanding homogeneous middleman groups functioning as adaptive units. The various case studies of HMGs in this paper collectively demonstrate the existence and evidence of the importance of cultural group selection in human society.

Acknowledgements Earlier versions of the paper were presented at the 'Bioeconomics' panel, Public Choice Society meetings, March 22-24, 2002, San Diego, California; 'Evolutionary Approaches to Religion' organized by Richard Sosis, at the annual meeting of the Society for the Scientific Study of Religion's Conference on 'Religion, Economics, and Culture' held October 22-24, 2004, Kansas City, Missouri; the 'Evolutionary Concepts in Economics and Biology' Workshop held at the Max Planck Institute for Research into Economic Systems in Jena, Germany, Dec. 2-4, 2004 and at the Department of Economics, University of Turin, May 19, 2005. I thank the late Jack Hirshleifer for helpful comments on an early version of the paper, and to Michael Ghiselin and Alexander Field for helpful comments on a recent version of the paper. Finally, I thank David Sloan Wilson for encouraging me to write this paper as a target paper and providing helpful comments on the final version of this paper.

Open Access This article is distributed under the terms of the Creative Commons Attribution Noncommercial License which permits any noncommercial use, distribution, and reproduction in any medium, provided the original author(s) and source are credited.

\section{References}

Alexander, R. (1987). The biology of moral systems. New York: Aldine De Gruter.

Bernstein, L. (1992). Opting out of the legal system: Extralegal contractual relations in the diamond industry. Journal of Legal Studies, 21(1):115-157.

Barth, F. (Ed.). (1969). Ethnic groups and boundaries. Boston: Little, Brown \& Co.

Boyd, R., \& Richerson, P. (1980). Sociobiology, culture and economic theory. Journal of Economic Behavior and Organization, 1, 97-121.

Boyd, R., \& Richerson, P. (1985). Culture and the evolutionary process. Chicago: University of Chicago Press.

Bowles, S., \& Gintis, H. (2004). Persistent parochialism: Trust and exclusion in ethnic networks. Journal of Economic Behavior and Organization, 55, 1-23.

Buchanan, J. M. (1965). An economics theory of clubs. Economica 32(February), 1-14.

Buchanan, J. M. (2000). Group selection and team sports. Journal of Bioeconomics, 2(1), 1-7.

Carr, J., \& Landa, J. T. (1983). The economics of symbols, clan names and religion. Journal of Legal Studies, 13, 135-156.

Cooter, R., \& Landa, J. T. (1984). Personal versus impersonal trade: The size of trading groups and contract law. International Review of Law and Economics, 4, 15-22.

Corning, P. (2007). Synergy goes to war: A bioeconomic theory of collective violence. Journal of Bioeconomics, 9(2), 109-144.

Curtin, P. D. (1984). Cross cultural trade in world history. Cambridge: Cambridge University Press.

Dawkins, R. (1976). The selfish gene. Oxford: Oxford University Press. 
Dotson, F., \& Dotson, L. O. (1968). The Indian minority of Zambia, Rhodesia, and Malawi. New Haven, CT: Yale University Press.

Dotson, F., \& Dotson, L. O. (1975). The economic role of non-indigenous ethnic minorities in Colonical Africa. In P. Duignan \& L. G. Gann (Eds.), The economics of colonialism in Africa, 1870-1960 (Vol. 4). Cambridge: Cambridge University Press.

Fehr, E., \& Gächter, S. (2002). Altruistic punishment in humans. Nature, 13, 137-140.

Field, A. (2001). Altruistically inclined? The behavioral sciences, evolutionary theory, and the origins of reciprocity. Ann Arbor, MI: University of Michigan Press.

Field, A. (2008). Why multilevel selection matters. Journal of Bioeconomics Special Issue, 10(3). doi:10. 1007/s10818-007-9018-1.

Gifford, A., Jr. (2000). The bioeconomics of cooperation. Journal of Bioeconomics, 2(2), 153-168.

Godsell, G. (1991). Entrepreneurs embattled: barriers to entrepreneurship in South Africa. In B. Berger (Ed.), The culture of entrepreneurship (pp. 85-97). San Francisco, CA: ICS Press.

Greif, A. (1993). Contract enforceability and economic institution in early trade: the Maghribi traders. American Economic Review, 83, 525-548.

Gutwirth, J. (1968). Antwerp Jewry today. Jewish Journal of Sociology, 10, 121-137.

Hamilton, W. D., \& Zuk. M. (1989). Parasites and sexual selection. Nature, 341, 289-290.

Hirshleifer, J. (1982). Evolutionary models in economics and law: Cooperation versus conflict strategies. Research in Law and Economics, 4, 1-60.

Hirshleifer, J. (1999). There are many evolutionary pathways to cooperation. Journal of Bioeconomics, 1, 73-93.

Holland, J. H. (1975). Adaption in natural and artificial systems: An introductory analysis with applications to biology, control, and artificial intelligence. Ann Arbor, MI: University of Michigan Press.

Iannaccone, L. R. (1992). Sacrifice and stigma: Reducing free-riding in cults, communes and other collectives. Journal of Political Economy, 100, 271-211.

Iyer, G. R. (1999). The impact of religion and reputation in the organization of Indian merchant communities. The Journal of Business and Industrial Marketing, 14(2), 102-121.

Laidlaw, J. (1995). Riches and renunciation: Religion, economy, and society among the Jains. Oxford: Oxford University Press.

Landa, J. T. (1978). The economics of the ethnically homogeneous Chinese middleman group: A property rights-public choice approach. Unpublished Ph.D. Dissertation, Virginia Polytechnic Institute and State University.

Landa, J. T. (1981). A theory of the ethnically homogeneous middleman group: an institutional alternative to contract law. The Journal of Legal Studies, 10, 349-362.

Landa, J. T. (1983). The political economy of the ethnically homogeneous Chinese middleman group in Southeast Asia: Ethnicity and entrepreneurship in a plural society. In L. Y. C. Lim \& L. A. P. Gosling (Eds.), The Chinese in Southeast Asia. Vol. 1. Ethnicity and economic activity (pp. 86-116). Singapore: Maruzen Asia.

Landa, J. T. (1986). The political economy of swarming in honeybees: Voting-with the wings, decisionmaking costs, and the unanimity rule. Public Choice, 51, 26-38.

Landa, J. T. (1988). Underground economies: Generic or sui generis? In J. Jenkins (Ed.), The informal sector: Including the excluded (pp. 75-102). San Francisco, CA: ICS Press.

Landa, J. T. (1991). Culture and entrepreneurship in less-developed countries: Ethnic trading networks as economic organizations. In B. Berger (Ed.), The culture of entrepreneurship (pp. 53-72 and notes pp. 217-222). San Francisco, CA: ICS Press.

Landa, J. T. (1994). Trust, ethnicity, and identity: The new institutional economics of ethnic trading networks, contract law, and gift-exchange. Ann Arbor, MI: University of Michigan Press.

Landa, J. T. (1998). The co-evolution of markets, entrepreneurship, laws, and institutions in China's economy in transition: A new institutional economic perspective. University of British Columbia Law Review, 32(2), 391-421.

Landa, J. T, (1999a). Bioeconomics of some nonhuman and human societies: New institutional economics approach. Journal of Bioeconomics, 1(1), 95-113.

Landa, J. T. (1999b). The law and bioeconomics of ethnic cooperation and conflict: A theory of Chinese merchant success. Journal of Bioeconomics, 1(3), 269-284.

Landa, J. T. (2002). Cognitive and classificatory foundations of trust and informal institutions: A new and expanded theory of ethnic trading networks. In F. K. Salter (Ed.), Risky transactions: Trust, kinship, and ethnicity (pp. 129-142). New York: Berghahn Books. 
Landa, J. T., \& Salaff, J. (1980) [revised 1986]. The socio-economic functions of kinship and ethnic networks in the growth of a Chinese family firm in Singapore: A transaction costs approach. [Unpublished manuscript].

Lumsden, C. J., \& E. O. Wilson. (1981). Genes, mind, and culture. The coevolutionary process. Cambridge: Harvard University Press.

Lumsden, C. J., \& E. O. Wilson. (2005). Genes, mind, and culture. The coevolutionary process:25th Anniversary Edition, with a new Introduction. Hackensack, NJ: World Scientific.

Metcalfe, J. S. (2008). Accounting for economic evolution: Fitness and the population method. Journal of Bioeconomics, 10(2), 23-29.

Michod, R. E. (1997). Cooperation and conflict in the evolution of individuality. I. Multilevel selection of the organism. The American Naturalist, 149(4), 607-645.

Richerson, P. J. \& Boyd, R. (2005). Not by genes alone: How culture transformed human evolution. Chicago: University of Chicago Press.

Richman, B. D. (2006). How community institutions create economic advantage: Jewish diamond merchants in New York. Law \& Social Inquiry, 31(2), 383-420.

Rubin, P. H. (2000). Group selection and the limits of altruism. Journal of Bioeconomics, 2(1), 9-23.

Sober, E. \& Wilson, D. S. (1998). Unto others: The evolution and psychology of unselfish behavior. Cambridge: Harvard University Press.

Tilly, C. (2005). Trust and rule. Cambridge: Cambridge University Press.

Udovitch, A. L., \& Valensi, L. (1984). The last Arab Jews: The communities of Jerba. Tunisia: Harwood Academic Publishers.

Watson, A. (1988). The reform of agricultural marketing in China since 1978. China Quarterly, 113, 1-28.

Wilson, D. S. (1975). A theory of group selection. Proceedings of the National Academy of Sciences, 72 , 143-146.

Wilson, D. S. (2000). Religious groups and homogeneous merchant groups as adaptive units: A multilevel evolutionary perspective [Letter to the Editors]. Journal of Bioeconomics, 2(3), 271-273.

Wilson, D. S. (2002). Darwin's cathedral: Evolution, religion, and the nature of society. Chicago: University of Chicago Press.

Wilson, D. S. (2004). Testing major evolutionary hypotheses about religion with a random sample. [July 20 unpublished manuscript].

Wilson, D. S., \& Wilson, E. O. (2007). Rethinking the theoretical foundation of sociobiology. The Quarterly Review of Biology, 82(4), 328-348.

Wilson, D. S. \& Wilson, E. O. (2008). Evolution "for the good of the group." American Scientist, 96(5), 380-389.

Zenner, W. P. (1983). The Jewish diaspora and the middleman adaptations. In Levine E. (Ed.), Diaspora: Exile and the Jewish condition. New York: Jason Aronson. 